\title{
ASPECTS OF LYOPHILIZATION OF CARDIAC BIOIMPLANT
}

\author{
N.V. Shchotkina* \\ Center for Pediatric Cardiology and Cardiac Surgery, Kyiv, Ukraine \\ *Corresponding author: cardiotissue@gmail.com \\ Received 19 October 2021; Accepted 25 November 2021
}

The use of implants of biological origin in clinical practice has led to the search for methods of long-term storage of tissues without damaging their functional and structural characteristics. Xenografts (extracted from pericardium of pigs, horses, bulls) are drawing more and more interest. The bovine pericardium is exposed to chemical and physical factors providing complete purification of tissue from cells and their components. Such scaffolds are protein (collagen) complexes that fully replicate the microstructure of the pericardial tissue. Lyophilisation ensures long-term preservation of the extracellular matrix properties. The principle of the method is in drying pre-frozen tissue, in which water is sublimated. The method is intended for storage, transportation, and the subsequent use of the bioimplant in clinical practice. However, the lyophilization process may be accompanied by various undesirable factors that can lead to denaturation of the matrix protein or loss of its functionality and structure. To preserve the natural microstructure, stabilizers or various modifications (slow/fast freezing, reducing the degree of supercooling, etc.) of the lyophilization process are applied to biological prostheses. In this review, the main processes of lyophilization of biological tissue are described, which can affect the operation of a cardiac implant. A deep understanding of the parameters of the lyophilization process is crucial for creation of stable tissue grafts and their subsequent long-term storage.

Keywords: scaffold; lyophilization; tissue engineering; bovine pericardium; extracellular matrix.

\section{Introduction}

Modern treatments for heart failure are aimed at correcting (masking) symptoms and while the latest research strategies are aimed at eliminating the causes of their occurrence - repairing damaged myocardium or regenerating it, often regenerative medicine approaches are used. Despite recent advances in this field, few patients fully restore heart function. Today, the most effective treatment for patients with end-stage heart failure is cardiac allotransplantation [1, 2]. However, the number of patients requiring transplantation significantly exceeds the number of donor hearts [3]. Therefore, the development of alternative treatments for heart failure remains a top priority. One of the possible methods is the use of xenograft-derived scaffolds which is a decellularized matrix, these scaffolds are used to replace or support damaged heart tissue. The decellularized scaffold can be applied to the surface of the heart to prevent, or even regress, the spread of heart damage. Also, grafts that are to a certain extent populated with cells and delivered to the site of injury can help restore lost heart cells and further recovery. An ideal scaffold should be compatible with all types of heart cells, provide mechanical strength in the right place, properly order cells and transmit biochemical signals for the proper functioning of cells in the heart [4]. Sources of such scaffolds can be biological or synthetic materials, each of which has its own advantages and disadvantages. Synthetic materials are not always biodegradable and often do not meet the requirements for the attachment and infiltration of cells in the vessels and parenchyma; however, it is convenient to make grafts of almost any size and shape from them [5].

Unlike synthetic scaffolds, biological ones, which usually originate from the extracellular matrix (ECM), support the transmission of biochemical signals necessary for cell migration, proper positioning, and differentiation. However, they can be mechanically unstable when exposed to physical conditions (sterilization, lyophilization, etc.).

One of the widely used methods for the preservation of donor tissues is lyophilization - a method of drying pre-frozen tissue intended for long-term storage and its further use (after rehydration) in clinical practice. The peculiarity of this method lies in the fact that drying occurs during the transition of water from a solid state to steam, bypassing the liquid phase [6]. Drying of tissues during lyophilization leads to dehydration of the amorphous matrix surrounding the collagen fibers. As a result, certain structural transformations of the biotechnologically transformed tissue matrix occur [7]. For the first time, a systematic study of the properties and qualities of lyophilized grafts 
took place in the 1950s of the last century. Some of the first researches devoted to tissue lyophilisation belong to E.W. Flosdorf [8]. To date, a fairly large number of studies have been devoted to comprehensive research of lyophilized graft architectonics and biomechanical properties [9, 10]. Scientists have proven that during lyophilisation tissues acquire resistance to environmental factors and the ability to maintain a complex of structural and biochemical properties that are important for the transplantation [11, 12]. In addition, lyophilisation of xenograft is necessary prior to gamma-ray sterilization to avoid substantial changes in the tissues without dehydration that make impossible their clinical use. The lyophilisation process does not significantly affect the structure of tissues such as bone, cartilage and pericardium [13].

Lyophilized bovine pericardial transplants treated with glutaraldehyde are used in surgery for heart valve replacement. The use of such scaffolds often leads to implant calcification. However, some authors report that lyophilisation before chemical treatment reduces inflammation and prevents calcification, as well as not changing the mechanical characteristics of the biomaterial; it does improve its immune properties, and allows the graft to be preserved for future use [14].

Scientific advances in tissue engineering make it possible to create grafts using various chemical and physical methods. At the same time, the influence of the lyophilisation process on the properties of new grafts requires further study, which determines the relevance of the selection of the optimal parameters and reagents of the method (Figure). The structure of the lyophilisation process can have a significant impact on tissue stability. To reduce structural damage and preserve the natural properties of the fabric, it is necessary to analyse the freezing rate and temperature, drying rate and moisture content in stages. Therefore, the purpose of this review was to consider the main processes of lyophilization and its effect on biological tissues.

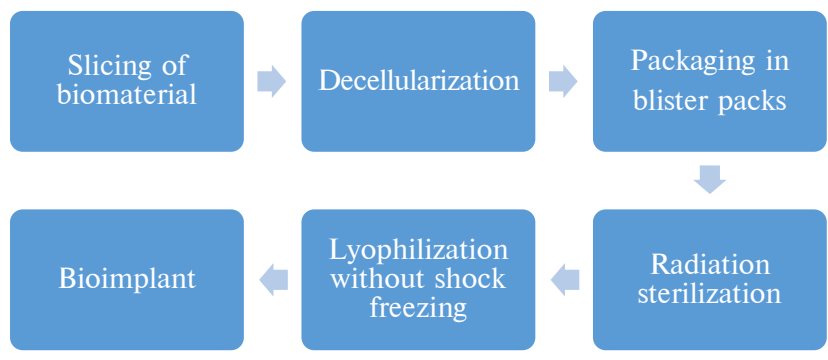

Figure: Scheme of creating a lyophilized bioimplant

\section{Modern approaches to long-term storage of biological tissues}

Lyophilisation is one of the most effective techniques for the long-term storage of tissues for surgical use. The peculiarity of this method is that drying takes place during the transition of water from a solid state to vapour without a liquid phase [15]. This phenomenon of evaporation of a solid without melting is called freeze drying. The displacement of moisture from a frozen state of biological tissue is due to the property of water to pass from the state of ice to the vapour state at temperatures below zero, under the influence of vacuum and at a pressure of less than $4.6 \mathrm{~mm} \mathrm{Hg}$, that is, the solid passes into vapour without the formation of an intermediate liquid state. It is important that during lyophilisation to create conditions that regulate tissue temperature and water vapour pressure to ensure a continuous transition of ice to steam. The crystallization temperature is usually determined by measuring the conductivity of an electric current [16, 17]. Dehydration is carried out by maintaining the equilibrium of the concentration of water vapour in the tissue and the environment. If the space around the tissue is released from water vapour, their loss is compensated by the sublimation of an appropriate amount of water vapour from the frozen tissue [18].

Freeze drying of biological tissue (homo- or heterograft) aims to create an implant bank for use in modern cardiac surgery. Lyophilisation ensures optimal preservation of all functional properties and architectonics of the extracellular matrix (ECM) of the cardiac implant. This method avoids the problem of storing frozen tissues due to the transition of the tissue into a dry form. Lyophilisation is used for storage of bio-prostheses and in tissue engineering $[19,20]$.

The lyophilisation process includes the stages of freezing, primary and secondary drying, taking into consideration stability of the protein, the characteristics of the inert filler, and the critical temperatures of the structure [21].

Freezing is the initial stage using several such freezing agents as liquid nitrogen, liquid oxygen and dry ice. When freezing biological materials, the cooling rate plays an important role, on which the size of the ice crystals depends. With fast freezing, a fine-crystalline structure of the frozen tissue is formed, with slow freezing, a coarse-crystalline one is formed. The formation of ice crystals and their 
size depends to a large extent on the degree of hypothermia, the start point of crystallization temperature and of cooling rate [22-24]. In order to obtain frozen tissue without microscopically visible crystals, the temperature must be reduced every second by $10-20^{\circ} \mathrm{C}$, since slow freezing allows water to crystallize [25]. The cooling rate of biological tissue for conservation depends mainly on the cooling temperature, the nature of the environment and the size of the tissue being processed [26]. Under optimal conditions, freezing forms large ice crystals with minimal surface area.

Annealing is a stage of the freezing process during which the product temperature is kept higher than the final freezing temperature for a sufficiently long time. Annealing promotes the crystallization of inert fillers (mannitol and glycine), which in turn prevents the breakdown of matrix proteins and strengthens their storage stability [27-29].

Primary dehumidification. The next stage is the evaporation of the solution from the ice, which occurs at an increasing product temperature, but within the limits below the critical temperature (glass transition temperature and collapse temperature). This process can be controlled by the pressure in the lyophilisation chamber providing that the pressure in the chamber is lower than the pressure of saturated water vapour at the required temperature [30]. The difference between the pressure in the chamber and the vapour pressure serves as the driving force for the sublimation reaction. $\mathrm{Pa}$ rameters of the primary drying process, such as temperature and duration, heating intensity, pressure in the chamber, can affect the quality of the final product.

Secondary dehumidification. Residual moisture is removed by secondary dehumidification using desorption. Compared to the primary process, the product temperature is higher and the chamber pressure is lower [31]. When heating during primary drying to the temperature at the beginning of secondary drying, excessive increase heating intensity should be avoided to prevent both protein denaturation and product polymerization [32]. In general, it is recommended to set a high temperature for a short period in order to reduce the lyophilisation duration. The temperature, the pressure in the chamber and the duration of secondary drying must be optimized taking into account the required moisture content of the dried product, which is necessary to preserve the protein structure [33].

\section{Unfavourable aspects during lyophilisation of biological tissues}

Biomaterials for implants in cardiac surgery are an extracellular matrix (collagen protein) purified from cells and their components. The structure of water around collagen was investigated by various methods [18]. It has been shown that water plays an important role in maintaining the microstructure of the collagen matrix and provides the mechanical properties of collagen fibrils [34]. Water can interact with collagen in three states: free, bound, or structural. Free water fills the space between the microfibrils and the protein fibrils. At the same time, the bound water stabilizes the collagen double helix. Structural water is responsible for the stabilization of the protein triple helix by forming hydrogen bonds between the helix [26]. These differences lead to a significant effect on the dynamics of water removal and the composition of residual moisture in dry preparations. The amount of bound water, as well as the strength of its binding to the substrate that is measured by the binding energy in different preparations, can vary widely depending on the type of tissue that is subjected to conservation [18].

Water molecules coming out of tissue can behave in different ways. Very often, water molecules from the inside of the tissue turn back into ice on the surface of the tissue. In other cases, water molecules freely leave the tissue and are retained by the condenser of the lyophilizer. The resistance that water molecules meet on their way is due to the shape and size of the tissue and the thickness of the dried layer. The thinner the tissue, the smaller its size and the faster it cleans from the water. An important factor in tissue dehydration is its residual moisture, which affects the preservation of the morphological structures of the tissue that is being preserved. Residual moisture is defined as the percentage between the weight of the native and lyophilized biological tissue. The acceptable degree of dehydration for vessels is a threshold within $5 \%$ of residual free water [35].

At the end of the first drying period, when the free water is completely removed, the temperature rises to about $0{ }^{\circ} \mathrm{C}$. The residual moisture of the tissue, due to the presence of the bound water, remains at $5-10 \%$ of the dry mass. This moisture could not be removed under the physical conditions that are characteristic of the first drying period. In the second period, when the temperature of the material rises to $+30-+40{ }^{\circ} \mathrm{C}$, conditions 
are created for the water removal, which is bound to the substrate by stronger bonds. Until the end of the second period, the residual tissue moisture usually decreases to $1-2 \%$ [36].

Thus, the lyophilisation process can significantly damage the microstructure of the ECM, which is important for the effective operation of the biological prosthesis. At this time, various chemical and physical methods are used to preserve the structure of the matrix after freeze drying. One of the widely used methods is the use of glutaraldehyde (GA) as a crosslinking agent. GA stabilizes the collagen structure, prevents the destruction of tissues by enzymes or bacteria, and also reduces the antigenicity of the material [37]. However, the use of GA may result in uneven collagen linking (surface linking), which may result in the formation of multilayer material and, as a consequence, a limitation of the mechanical properties of the valve leaflets under cyclic loads. M. LopezMoya et al. mention that the main controversial aspect of this method is the appearance of a progressive calcification process leading to deterioration in the structure of the bio-prosthesis and loss of its function [38]. To eliminate the process of calcification of bio-prostheses, several methods have been proposed, such as: treatment with heparin, hyaluronic acid coatings and photochemical crosslinking [39].

Complete rejection of GA is possible with cross-linking using soluble carbodiimide (1-ethyl3-(3-dimethylaminopropyl) carbodiimide) and an organic substance derived from proline (N-hydroxysuccinimide). Stabilization of the "cross-linking" process is carried out in the MES buffer $(2-(\mathrm{N}$ morpholino) ethanesulfonic acid). The effectiveness of this technique was positively assessed according to the results of the biomechanical properties of the implant [40].

However, the successful course of the lyophilisation process depends not only on the presence of a stabilizing agent, but also on factors such as crystallization, $\mathrm{pH}$ shift, formation of ice crystals and so on. A change in the chemical equilibrium in the system during lyophilisation can lead to protein denaturation and loss of its biological activity.

Freezing can cause structural and conformational changes in the protein, which are usually reversible. During lyophilisation, a two-phase matrix is formed, consisting of ice and a frozen matrix, containing solvent molecules and a fraction of water that is not frozen. The solidification of the frozen matrix leads to separation into a phase without ice and a phase with ice [41]. Protein products may become unstable during freezing and crystallization. The cause of instability during lyophilisation is incomplete crystallization of cryoprotectants.

Crystalline inert fillers such as mannitol and glycine must be completely crystallized upon freezedrying because complete crystallization of mannitol can result in further crystallization during storage, which, in turn, can lead to loss of protein stability [42]. Taking into account the properties of crystallization and characteristics of metastable forms during transformation is a prerequisite for the development of stable protein products [43]. A review of previous publications suggests that crystallization with cryoprotectants is one of the main protein destabilizing factors. Thus, the choice of cryoprotectants with a low tendency to crystallization can be a solution to ensure stability and preserve the biological activity of the protein in the frozen state [44, 45].

Protein products are stable at isoelectric $\mathrm{pH}$ values between 6 and 7. At higher values, the repulsion of the same charges of the protein molecules occurs, which causes its denaturation or unfolding. The change in $\mathrm{pH}$ in a frozen product can be observed during freezing of components which contain less soluble buffer components. During freezing of a protein product with such buffer components as sodium phosphate and succinate, their possible crystallization results in a decrease in $\mathrm{pH}$ by 3 units, which significantly destabilizes proteins [46, 47]. When such salts as sodium or potassium phosphates are used as buffering components, the difference between the freezing point of monoionized (salt) and non-ionized (free acid or base) samples causes one component to freeze earlier than the other, leading to destabilization of proteins (denaturation or conformational changes) [48].

Thus, biological tissues dried by the freezedrying method differ significantly in their properties from similar tissues dried from a liquid state. A characteristic feature of lyophilized tissues is their almost complete keeping the original volume turning into a dry sponge. Before use, lyophilized tissues are placed in sterile saline solution, which may contain antibiotics (penicillin, streptomycin, gentamicin) for further rehydration. The essence of rehydration is that the lyophilized tissue absorbs moisture and again acquires the properties characteristic of the original state. With the correct rehydration regimen, the physicochemical, plastic and structural features of the pericardium can be restored.

Lyophilized tissue when packed under vacuum, can be stored indefinitely both in a refrige- 
rated state and at room temperature. However, today, according to the standards, freeze-dried xenoand allografts are recommended to be stored for no more than 5 years. Transportation and storage of such tissues are also carried out without any special conditions and reservations [35].

\section{Conclusions}

According to the analytical review, it was determined that today a large number of biocompatible materials are used to create implants, but none of them are ideal, therefore, the search for new materials for plastic surgery of cardiovascular tissue is relevant at the current stage of tissue engineering development. Increasing preference is given to natural matrices, in particular an extracellular matrix based on the bovine pericardium, which has advantages over synthetic analogues. The production of xenograft-derived cardiac prostheses requires guaranteed shelf life and transportation con- ditions. Therefore, methods of long-term storage of bio-prostheses are being actively developed, which can provide storage without functional and structural changes in the implant. The most promising method for today is drying a bio-prosthesis by lyophilisation, which creates conditions under which biological tissues undergo minimal chemical changes. A lyophilized cardiac implant under vacuum packing can be stored indefinitely and does not require special transportation conditions. The possibility of long-term storage of lyophilized bio-prostheses for cardiac surgery, ease of transportation provides the opportunity to create a large supply of biomaterial. This makes it possible to create an almost unlimited supply of valuable material that can be transported at any time and over unlimited distances. Therefore, this method of preserving biomaterials in our time is considered to be one of the most promising and convenient for practical purposes and tasks.

\section{References}

[1] Yancy CW, Jessup M, Bozkurt B, Butler J, Casey DE Jr, Colvin MM, et al. 2017 ACC/AHA/HFSA focused update of the 2013 ACCF/AHA guideline for the Management of Heart Failure: a report of the American College of Cardiology/American Heart Association task force on clinical practice guidelines and the Heart Failure Society of America. Circulation. 2017;136(6):e137-61. DOI: 10.1161/CIR.0000000000000509

[2] Wilhelm MJ. Long-term outcome following heart transplantation: current perspective. J Thorac Dis. 2015;7(3):549-51. DOI: $10.3978 /$ j.issn.2072-1439.2015.01.46

[3] Longnus SL, Mathys V, Dornbierer M, Dick F, Carrel TP, Tevaearai HT. Heart transplantation with donation after circulatory determination of death. Nat Rev Cardiol. 2014 Jun;11(6):354-63. DOI: 10.1038/nrcardio.2014.45

[4] Wang B, Patnaik SS, Brazile B, Butler JR, Claude A, Zhang G, et al. Establishing early functional perfusion and structure in tissue engineered cardiac constructs. Crit Rev Biomed Eng. 2015;43(5-6):455-71. DOI: 10.1615/CritRevBiomedEng.2016016066

[5] Kaiser NJ, Coulombe KLK. Physiologically inspired cardiac scaffolds for tailored in vivo function and heart regeneration. Biomed Mater. 2015 May 13;10(3):034003. DOI: 10.1088/1748-6041/10/3/034003

[6] Klen R. Harvesting and preserving tissues. Praha: State Publishing House of Medical Literature; 1962.316 p.

[7] Shangina OR, Khasanov RA, Bulgakova LA. Regularities of the structure changes of the freeze-dried connective allotransplantats. Vestnik of the Orenburg State University. 2013;4:299-302.

[8] Flosdorf EW. Freeze-drying: drying by sublimation. New York: Reinhold Publishing Corporation; 1949. 280 p.

[9] Leal BBJ, Wakabayashi N, Oyama K, Kamiya H, Braghirolli DI, Pranke P. Vascular tissue engineering: polymers and methodologies for small caliber vascular grafts. Front Cardiovasc Med. 2021 Jan 11;7:592361. DOI: 10.3389/fcvm.2020.592361

[10] Olmos-Zúciga JR, Jasso-Victoria R, Díaz-Martunez NE, Gaxiola-Gaxiola MO, Sotres-Vega A, Heras-Romero Y, et al. Lyophilized allografts without pre-treatment with glutaraldehyde are more suitable than cryopreserved allografts for pulmonary artery reconstruction. Braz J Med Biol Res. 2016;49(2):e5001. DOI: 10.1590/1414-431X20155001

[11] Zuki AB, Hafeez YM, Loqman MY, Noordin MM, Norimah Y. Effect of preservation methods on the performance of bovine pericardium graft in a rat model. Anat Histol Embryol. 2007;36(5):349-56. DOI: 10.1111/j.1439-0264.2007.00772.x

[12] Offeddu GS, Ashworth JC, Cameron RE, Oyen ML. Multi-scale mechanical response of freeze-dried collagen scaffolds for tissue engineering applications. J Mech Behav Biomed Mater. 2015;42:19-25. DOI: 10.1016/j.jmbbm.2014.10.015

[13] Saveliev VI, Kornilov NV. Actual problems of tissue transplantation. Saint Petersburg: Morsarav; $2001.152 \mathrm{p.}$

[14] Aimoli CG, Nogueira GM, Nascimento LS, Baceti A, Leirner AA, Maizato MJ, et al. Lyophilized bovine pericardium treated with a phenethylamine-diepoxide as an alternative to preventing calcification of cardiovascular bioprosthesis: preliminary calcification results. Artif Organs. 2007;31(4):278-83. DOI: 10.1111/j.1525-1594.2007.00376.x

[15] Nail SL, Jiang S, Chongprasert S, Knopp SA. Fundamentals of freeze-drying. In: Nail SL, Akers MJ, editors. Development and manufacture of protein pharmaceuticals. Boston: Springer; 2002. p. 281-360. DOI: 10.1007/978-1-4615-0549-5_6 
[16] O'Brien FJ, Harley BA, Yannas IV, Gibson L. Influence of freezing rate on pore structure in freeze-dried collagen-GAG scaffolds. Biomaterials. 2004;25(6):1077-86. DOI: 10.1016/s0142-9612(03)00630-6

[17] Pikal MJ, Shah S. The collapse temperature in freeze drying: dependence on measurement methodology and rate of water removal from the glassy phase. Int J Pharm. 1990;62(2-3):165-86. DOI: 10.1016/0378-5173(90)90231-R

[18] Renou JP, Bonnet M, Bielicki G, Rochdi A, Gatellier P. NMR study of collagen-water interactions. Biopolymers. 1994 Dec;34(12):1615-26. DOI i: 10.1002/bip.360341206

[19] Buttafoco L, Kolkman NG, Engbers-Buijtenhuijs P, Poot AA, Dijkstra PJ, Vermes I, et al. Electrospinning of collagen and elastin for tissue engineering applications. Biomaterials. 2006 Feb;27(5):724-34. DOI: 10.1016/j.biomaterials.2005.06.024

[20] Faraj KA, van Kuppevelt TH, Daamen WF. Construction of collagen scaffolds that mimic the three-dimensional architecture of specific tissues. Tissue Eng. 2007 Oct;13(10):2387-94. DOI: 10.1089/ten.2006.0320

[21] Butreddy A, Dudhipala N, Janga KY, Gaddam RP. Lyophilization of small molecule injectables: an industry perspective on formulation development, process optimization, scale-up challenges, and drug product quality attributes. AAPS PharmSciTech. 2020 Sep 3;21(7):252. DOI: 10.1208/s12249-020-01787-w

[22] Heller MC, Carpenter JF, Randolph TW. Protein formulation and lyophilization cycle design: prevention of damage due to freeze-concentration induced phase separation. Biotechnol Bioeng. 1999 Apr 20;63(2):166-74 DOI: 10.1002/(sici) 1097-0290(19990420)63:2<166::aid-bit5>3.0.co;2-h

[23] Hottot A, Vessot S, Andrieu J. Freeze drying of pharmaceuticals in vials: influence of freezing protocol and sample configuration on ice morphology and freeze-dried cake texture. Chem Eng Process Process Intensif. 2007;46(7):666-74. DOI: $10.1016 /$ j.cep.2006.09.003

[24] Singh SN, Kumar S, Bondar V, Wang N, Forcino R, Colandene J, et al. Unexplored benefits of controlled ice nucleation: lyophilization of a highly concentrated monoclonal antibody solution. Int J Pharm. 2018 Dec 1;552(1-2):171-9. DOI: 10.1016/j.ijpharm.2018.09.057

[25] Petzold G, Aguilera JM. Ice morphology: fundamentals and technological applications in foods. Food Biophys. 2009;4:378-96. DOI: $10.1007 / \mathrm{s} 11483-009-9136-5$

[26] Jastrzebska M, Wrzalik R, Kocot A, Zalewska-Rejdak J, Cwalina BJ. Hydration of glutaraldehyde-fixed pericardium tissue. J Raman Spectrosc. 2003;34(6):424-31. DOI: 10.1002/jrs.1016

[27] Tang X, Pikal MJ. Design of freeze-drying processes for pharmaceuticals: practical advice. Pharm Res. 2004 Feb;21(2):191-200. DOI: $10.1023 / \mathrm{b}$ :pham.0000016234.73023.75

[28] Searles JA, Carpenter JF, Randolph TW. Annealing to optimize the primary drying rate, reduce freezing-induced drying rate heterogeneity, and determine T(g)' in pharmaceutical lyophilization. J Pharm Sci. 2001 Jul;90(7):872-87. DOI: 10.1002/jps.1040

[29] Schwegman JJ, Hardwick LM, Akers MJ. Practical formulation and process development of freeze-dried products. Pharm Dev Technol. 2005;10(2):151-73. DOI: 10.1081/pdt-56308

[30] Kawasaki H, Shimanouchi T, Kimura Y. Recent development of optimization of lyophilization process. J Chem. 2019;2019:9502856. DOI: 10.1155/2019/9502856

[31] Schneid SC, Gieseler H, Kessler WJ, Luthra SA, Pikal MJ. Optimization of the secondary drying step in freeze drying using TDLAS technology. AAPS PharmSciTech. 2011 Mar;12(1):379-87. DOI: 10.1208/s12249-011-9600-7

[32] Lim J, Kim NA, Lim DG, Kim KH, Choi D, Jeong S. Process cycle development of freeze drying for therapeutic proteins with stability evaluation. J Pharm Investig. 2016;46:519-36. DOI: 10.1007/s40005-016-0275-7

[33] Fissore D, Pisano R, Barresi AA. Monitoring of the secondary drying in freezedrying of pharmaceuticals. J Pharm Sci. 2011 Feb;100(2):732-42. DOI: 10.1002/jps.22311

[34] Bella J, Eaton M, Brodsky B, Berman HM. Crystal and molecular structure of a collagen-like peptide at $1.9 \mathrm{E}$ resolution. Science. 1994 Oct 7;266(5182):75-81. DOI: 10.1126/science.7695699

[35] Wolkers WF, Oldenhof H. Principles underlying cryopreservation and freeze-drying of cells and tissues. In: Cryopreservation and Freeze-Drying Protocols. New York: Humana. p. 3-25. DOI: 10.1007/978-1-0716-0783-1_1

[36] Polak R, Pitombo RNM. Care during freeze-drying of bovine pericardium tissue to be used as a biomaterial: a comparative study. Cryobiology. 2011 Oct;63(2):61-6. DOI: 10.1016/j.cryobiol.2011.05.001

[37] Neuenschwander S, Hoerstrup SP. Heart valve tissue engineering. Transpl Immunol. 2004 Apr;12(3-4):359-65. DOI: 10.1016/j.trim.2003.12.010

[38] Lopez-Moya M, Melgar-Lesmes P, Kolandaivelu K, de la Torre Hernández JM, Edelman ER, Balcells M. Optimizing glutaraldehyde-fixed tissue heart valves with chondroitin sulfate hydrogel for endothelialization and shielding against deterioration. Biomacromolecules. 2018 Apr 9;19(4):1234-44. DOI: 10.1021/acs.biomac.8b00077

[39] Moore MA, Bohachevsky IK, Cheung DT, Boyan BD, Chen WM, Bickers RR, et al. Stabilization of pericardial tissue by dye-mediated phtooxidation. J Biomed Mater Res. 1994 May;28(5):611-8. DOI: 10.1002/jbm.820280511 
[40] Sokol AA. Biomechanical properties of scaffolds for cardiac repair and regeneration. In: Proceedings of IX International Conference Medical Physics Current State Issue Development Directions New Technologies; 2020 Sep 23-25; Kyiv. p. 14852.

[41] Maïga A, Vera L, Marchetti C, Lorphelin A, Bellanger L, Mourier G, et al. Crystallization of recombinant green mamba c-Dala toxin during a lyophilization procedure and its structure determination. Acta Crystallogr Sect F Struct Biol Cryst Commun. 2013 Jun;69(Pt 6):704-9. DOI: 10.1107/S1744309113011470

[42] Horn J, Friess W. Detection of collapse and crystallization of saccharide, protein, and mannitol formulations by optical fibers in lyophilization. Front Chem. 2018 Jan 26;6:4. DOI: 10.3389/fchem.2018.00004

[43] Cao W, Xie Y, Krishnan S, Lin H, Ricci M. Influence of process conditions on the crystallization and transition of metastable mannitol forms in protein formulations during lyophilization. Pharm Res. 2013 Jan;30(1):131-9. DOI: 10.1007/s11095-012-0855-9

[44] Connolly BD, Le L, Patapoff TW, Cromwell MEM, Moore JMR, Lam P. Protein aggregation in frozen trehalose formulations: effects of composition, cooling rate, and storage temperature. J Pharm Sci. 2015 Dec;104(12):4170-84. DOI: 10.1002/jps.24646

[45] Singh SK, Kolhe P, Mehta AP, Chico SC, Lary AL, Huang M. Frozen state storage instability of a monoclonal antibody: aggregation as a consequence of trehalose crystallization and protein unfolding. Pharm Res. 2011 Apr;28(4):873-85. DOI: $10.1007 / \mathrm{s} 11095-010-0343-\mathrm{z}$

[46] Pikal-Cleland KA, Rodríguez-Hornedo N, Amidon GL, Carpenter JF. Protein denaturation during freezing and thawing in phosphate buffer systems: monomeric and tetrameric beta-galactosidase. Arch Biochem Biophys. 2000 Dec 15;384(2):398-406. DOI: $10.1006 /$ abbi.2000.2088

[47] Van Den Berg L, Rose D. Effect of freezing on the $\mathrm{pH}$ and composition of sodium and potassium phosphate solutions; the reciprocal system $\mathrm{KH}_{2} \mathrm{PO}_{4}-\mathrm{Na}_{2}-\mathrm{HPO}_{4}-\mathrm{H}_{2} \mathrm{O}$. Arch Biochem Biophys. 1959 Apr;81(2):319-29. DOI: 10.1016/0003-9861(59)90209-7

[48] Ugwu SO, Apte SP. The Effect of Buffers on Protein Conformational Stability. Pharmaceut Technol. 2004;28:86-108.

\section{Н.В. Щоткіна}

Центр дитячої кардіології та кардіохірургії, Київ, Украина

\section{ПРИНЦИПИ ЛІОФІЛІЗАЦІї БІОЛОГІЧНИХ КАРДІОІМПЛАНТІВ}

Використання в клінічній практиці імплантів біологічного походження обумовило пошук методів довготривалого зберігання тканин без пошкодження їх функціональних і структурних особливостей. Усе більший інтерес викликають імпланти, виготовлені з ксенотканин (перикарда свиней, коней, биків). Бичачий перикард піддають дії хімічних і фрізичних чинників, що забезпечують повне очищення тканини від клітин та їх компонентів. Такі скафолди являють собою білкові (колагенові) комплекси, що повністю відтворюють мікроструктуру перикардіальної тканини. Ліофілізація забезпечує збереження властивостей екстрацелюлярного матриксу протягом тривалого часу. Принцип методу полягає у висушуванні попередньо замороженої тканини, за якого вода повністю сублімується. Метод призначений для зберігання, транспортування та подальшого використання біоімпланта в клінічній практиці. Однак процес ліофілізації може супроводжуватися різними несприятливими чинниками, що можуть призводити до денатурації білка матриксу або втрати його функціональності та структурності. Для збереження природної мікростурктури біопротеза використовують стабілізатори або різні модифікації (повільне/швидке заморожування, зменшення ступеня переохолодження тощо) процесу ліофілізації. В нашому огляді розглянуто основні процеси ліофілізації біологічної тканини, що можуть впливати на роботу кардіоімпланта. Глибоке розуміння параметрів процесу ліофілізації має вирішальне значення для створення стабільних тканинних трансплантатів із подальшим їх довготривалим зберіганням.

Ключові слова: скафолд; ліофілізація; тканинна інженерія; бичачий перикард; позаклітинний матрикс.

\section{Н.В. Щеткина}

Центр детской кардиологии и кардиохирургии, Киев, Украина

\section{ПРИНЦИПЫ ЛИОФИЛИЗАЦИИ БИОЛОГИЧЕСКИХ КАРДИОИМПЛАНТОВ}

Использование в клинической практике имплантов биологического происхождения привело к началу поиска методов длительного хранения ткани без повреждения структурных и функциональных особенностей. Большой интерес вызывают импланты, изготовленные из ксенотканей (перикарда свиней, лошадей, быков). Бычий перикард подвергают воздействию химических и физических фракторов, обеспечивающих полную очистку ткани от клеток и их компонентов. Такие скаффолды представляют собой белковые (коллагеновые) комплексы, которые полностью воспроизводят микроструктуру перикардиальной ткани. Лиофилизация обеспечивает сохранение свойств экстрацеллюлярного матрикса в течение длительного времени. Принцип метода заключается в высушивании предварительно замороженной ткани, при котором вода полностью сублимируется. Метод предназначен для хранения, транспортировки и последующего использования биоимпланта в клинической практике. Однако процесс лиофилизации может сопровождаться различными неблагоприятными факторами, которые могут приводить к денатурации белка матрикса или потере его функциональности и структурности. Для сохранения природной микростурктуры биопротеза используют стабилизаторы или различные модификации (медленное/быстрое замораживание, уменьшение степени переохлаждения и т.д.) процесса лиофилизации. В данном обзоре рассмотрены принципы процесса лиофилизации биологической ткани, которые могут влиять на работу кардиоимпланта. Глубокое понимание параметров процесса лиофилизации имеет решающее значение для создания стабильных тканевых трансплантатов с последующим их длительным хранением.

Ключевые слова: скаффолд; лиофилизация; тканевая инженерия; бычий перикард; внеклеточный матрикс. 